\title{
Comparing Performance of Government and Private Clients in Construction Projects: Contractors' Perspective
}

\author{
Hatmoko, J.U.D. ${ }^{{ }^{*}}$ and Khasani, R.R. ${ }^{1}$
}

\begin{abstract}
By nature, government and private projects have different characteristics, which influence client performance. This research aims to compare performance of government and private clients in construction projects as perceived by contractors. Six client performance indicators were used, i.e. understanding of project requirements, financial, decision making, management skills, supports for contractor, and client's attitude. Data were collected through questionnaire surveys filled in by 117 respondents. The results show that there is a significant difference between both types of client performance. Three variables related to financial indicators, i.e. timely payment, owner value estimate, and payment approval, rank in the bottom three of the government client performance, but in contrast rank in the top three of the private ones. These results suggest that the government clients' performance is perceived inferior to the private ones. Establishing a clients' forum for sharing knowledge and best practices would be a strategic solution to enhance clients' capacities.
\end{abstract}

Keywords: Client forum; client performance; construction project; government client; private client.

\section{Introduction}

It has been widely accepted that client performance plays important roles in a project's success. Together with contractors, clients interact and work during the construction phase to complete the project as agreed in the contract. As early as 1994, Latham Report 'Constructing the Team' [1] points out the strategic roles of clients in the construction industry. Commissioned by the UK government, this report aims to examine the acute problems in the construction industry and recommend for solutions. This report reminded that "Government should commit itself to being a best practice client. It should provide its staff with the training necessary to achieve this and establish benchmarking arrangements to provide pressure for continuing improvements in performance. Private clients have a leading role and should come together in a Construction Clients' Forum. Clients, and especially Government, continue to have a role in promoting excellence in design."

Later in 2008, Business and Enterprise Committee [2], emphasizes that "success in construction projects is driven by the knowledge and skills of the client".

\footnotetext{
${ }^{1}$ Department of Civil Engineering, Diponegoro University, Semarang 50275, INDONESIA

${ }^{*}$ Corresponding author; e-mail: jati.hatmoko@ft.undip.ac.id
}

Note: Discussion is expected before November, $1^{\text {st }} 2016$, and will be published in the "Civil Engineering Dimension" volume 19, number 1, March 2017.

Received 14 August 2016; revised 17 August 2016; accepted 21 August 2016
Other research also highlights the importance of client performance and its impact on project, Kometa et al. [3] highlight the importance of attributes of clients' organizations which influence project performance, i.e. financial stability of client, feasibility of the project, past performance of client, project characteristics, and client's duties. Ryd [4] examined the clients' perspective of the briefing process, and introduced construction client's tools for facilitating strategic briefing as an important part of project success. Hwang et al. [5] found that there is a significant contribution of clients to project rework which in turn impact on project cost, schedule and quality performance. These client related reworks increased project cost by $7.1 \%$ and caused project delay 3.3 weeks on the average. They also found "replacement of materials by the client" and "change of plans or scope by the client" as the most frequent factors to occur and have the highest impact on project.

This research aims to compare the performance of government and private clients in construction projects as perceived by contractors in Semarang, Indonesia and surrounding areas. The objectives are to identify performance variables of government and private clients in construction projects, and to examine the expected and the actual performance of clients.

\section{Typical Clients in the Construction Industry}

The client is described as construction client who develops a construction project from the inception to the commissioning and utilization [6]. There are 
different types of clients in construction project. They can be distinguished either by their experience in handling projects (experienced vs inexperience clients), or by types of institutions (government vs private clients). They can also be classified as one-off clients or repeat business/continuing clients, or sophisticated or naïve clients [6, 7]. Experienced clients, also known as frequent clients, in general are responsible for $60 \%$ of the value of construction work. However, almost $95 \%$ of construction clients are oneoff or occasional clients. Therefore, they typically have little knowledge or experience with construction projects, making them are less likely to comprehend how the industry works and maximize their role for projects success. Risks of project failure may increase as such [2].

By nature, government and private projects may have different characteristics. Government projects, for example, may have more complex and longer bureaucracy than private projects, which in turn may impact on client performance. Government clients undertake government funded projects. They could be in local or central government undertaking public facilities, such as public buildings, roads, bridges, dams, etc. Government projects typically are traditional route of procurement, i.e. design-bidbuild, while for private project are more flexible, e.g. design-bid-build (D/B/B), design-build (D/B), engineering-procurement-construction (EPC). Department for Business, Enterprise and Regulatory Reform's (BERR) [8] reported that Government of The United Kingdom holds over $31 \%$ of construction output compare to private of $69 \%$, meaning that the government is the largest single customer to the industry.

Private clients are institutions or companies which need assistance from contractors to build and maintain their private properties, such as building, roads, etc. They can use their own funding to build the project or obtain loan from financial institutions. As opposed to the government clients which are bound with certain regulation in project procurement, they may have more flexibility which may speed up and increase their performance. This argument is supported by Yunianto et al. [9] who compared two building projects which were built by government and private clients. The government adopted traditional procurement route (design-bidbuild), while the private client used design and build. They found that the private project has higher level of constructability in comparison to government funded project.

\section{Measuring Client Performance}

As client performance has significant impact on overall project performance, measuring client performance is very important. Some efforts have been made to measure client performance [10-12]. Alinaitwe [10] assessed client performance based on their responsibilities related to project costs, quality, schedule, and resources. Elforgani and Rahmat [11] relate clients' qualities with green building design performance. Soetanto et al. [12] proposed six indicators for measuring client performance, i.e. client understanding of project requirements, financial, decisions making, management skill, support against contractor, and client's attitude.

Clients' understanding of project requirements and ability to explain them to other parties are required to ensure that the scope and technical specifications of the work to be done. In relation to finance, the client has to ensure sufficient funding for the project, as well as timely payment and ease of payment approvals. Decisions making should be quick and appropriate to accelerate project progress. As client organizations are often multifaceted, many problems may arise in the decision making process internally. Unity of opinion from client's team may significantly affect project performance. Good management skills, including comprehensive administration system are prerequisite as clients have to deal with and manage other parties under their coordination. Clients' support against contractors, such as timely information, adequacy of the project duration, readiness of site, etc, clearly has positive impact on timely project completion. Client's attitude includes integrity, discipline and effective coordination, commitment, empathy, respect and trust, all of which have a significant impact on project's success.

\section{Research Method}

To measure both the government and private clients' performance, 29 variables in six categories of performance indicators were used, i.e. understanding of project requirements, financial, decision making, management skills, supports for contractor and client's attitude. These variables are adapted and developed from Soetanto et al. [12] and Hatmoko and Khasani [13]. The performance measured including the expected and actual performance. Data were collected through questionnaire surveys filled in by a total number of 117 respondents, consisting of 60 and 57 respondents which have experience with government and private projects, respectively. Their scope of projects includes buildings, waterworks, roads and bridges. The questionnaires basically ask the respondents on the expected and actual performance of government and private clients using a 1 to 5 Likert scale to indicate a range of very low to very high client performance. The expected performance reflects the ideal and level of importance of the client performance variables as perceived by 
Table 1. General Information of Respondents and Types of Projects

\begin{tabular}{clcc}
\hline \multirow{2}{*}{ Subject } & \multirow{2}{*}{ Qualification } & \multicolumn{2}{c}{ No of Respondents } \\
\cline { 3 - 4 } & & Goverment & Private \\
\hline Position & Top management & 25 & 26 \\
& Staff & 33 & 20 \\
& Site engineer & 2 & 11 \\
& & & \\
\hline Experience & $>15 \mathrm{yr}$ & 18 & 20 \\
& $10-15 \mathrm{yr}$ & 10 & 5 \\
& $5-10 \mathrm{yr}$ & 21 & 18 \\
& $<5 \mathrm{yr}$ & 11 & 14 \\
\hline
\end{tabular}

\begin{tabular}{clcc}
\hline \multirow{2}{*}{ Subject } & \multicolumn{2}{c}{ Qualification } & \multicolumn{2}{c}{ No of Respondents } \\
\cline { 3 - 4 } & Goverment & Private \\
\hline \multirow{4}{*}{ Education } & Vocational high school & 3 & 5 \\
& Diploma & 20 & 14 \\
& Undergraduate & 35 & 37 \\
& Postgraduate & 2 & 1 \\
\hline \multirow{5}{*}{ Project Types } & Building & 49 & 46 \\
& Waterworks & 33 & 27 \\
& Road & 29 & 23 \\
& Bridge & 10 & 7 \\
\hline
\end{tabular}

contractors, while the actual performance reflects the actual conditions of clients' performance. Statistical independent t-test was performed to confirm any significant differences in perceptions of performance of both types of clients (at $\alpha=5 \%$ ).

The null hypothesis was that there was no significant difference between government and private clients. Table 1 shows general information of the profile of respondents and type of projects. Briefly, based on their positions, experience, education, as well as variety of project types involved, this profile of respondents provides some assurance related to the quality of data used for this research.

\section{Results and Discussions}

The results show that the average of mean values of actual performance of government and private clients are 3.436 and 3.566, respectively (Table 2). These values are below the average of mean values of expected performance of government and private clients of 4.312 and 4.140 (Table 3). This indicates that although the actual performance of both types of clients is perceived to be good, in general the contractors clearly wish a higher level of client performance.

The mean values of actual performance of private clients are higher than government clients (significantly different at $\alpha=1 \%$ ), indicating that in general the private clients perform better than the government clients. This argument is also supported by the fact that the mean values of expected performance of government clients are higher than private clients (significantly different at $\alpha=1 \%$ ), suggesting that the higher expectation of contractors on government client performance are due to inferior performance of government clients.

The mean values of actual performance of government and private clients are shown in Table 2. It can be seen that out of 29 performance variables, five variables are significantly different (at

$\alpha=5 \%)$. Three of them are related to financial indicators, i.e. suitability of owner value estimate, timely payment by the client in accordance with contract, ease of payment approval on projects. The other two are related to decision making (i.e. clients are able to make decisions/solutions quickly and appropriately according to problems), and support against contractor (sufficient and timely information support). For all these five indicators, the mean values of actual performance of private clients are higher than the government ones. This simply means that the actual performances of private clients for these five variables are perceived better than the government ones.

Table 3 compares the expected performance of government and private clients. It can be seen that the mean values of the expected performance generally are not significantly different (at $\alpha=5 \%$ ). There are only nine variables of which the mean values are significantly different (at $\alpha=5 \%$ ), i.e. understand the construction process, sufficient and timely support of information, the adequacy of the project duration, readiness of site, support of addendum, commitment to quality, time and cost, empathy to the difficulties of contractors, proactive attitude, trust to the contractor. Interestingly, of these nine variables, all the mean values of expected performance of government clients are higher than the private ones. The higher mean values represent the higher expectation of contractors on the actual performance of government clients. This may also indicates that the actual performance of government clients is perceived insufficient, and the contractors wish more client performance improvement.

Table 4 shows the rank of actual performance variables for government and private clients based on the total weighted score of each variable. The top three actual performance variables of private clients are: suitability of owner value estimate, timely payment and ease of payment approval, all of which are related to financial indicator. Meanwhile the bottom three of the actual performance of private clients includes routine monitoring client progress, empathy to contractors, client's proactive attitude. 
Table 2. Mean Value of Actual Performance for Goverment \& Private Clients

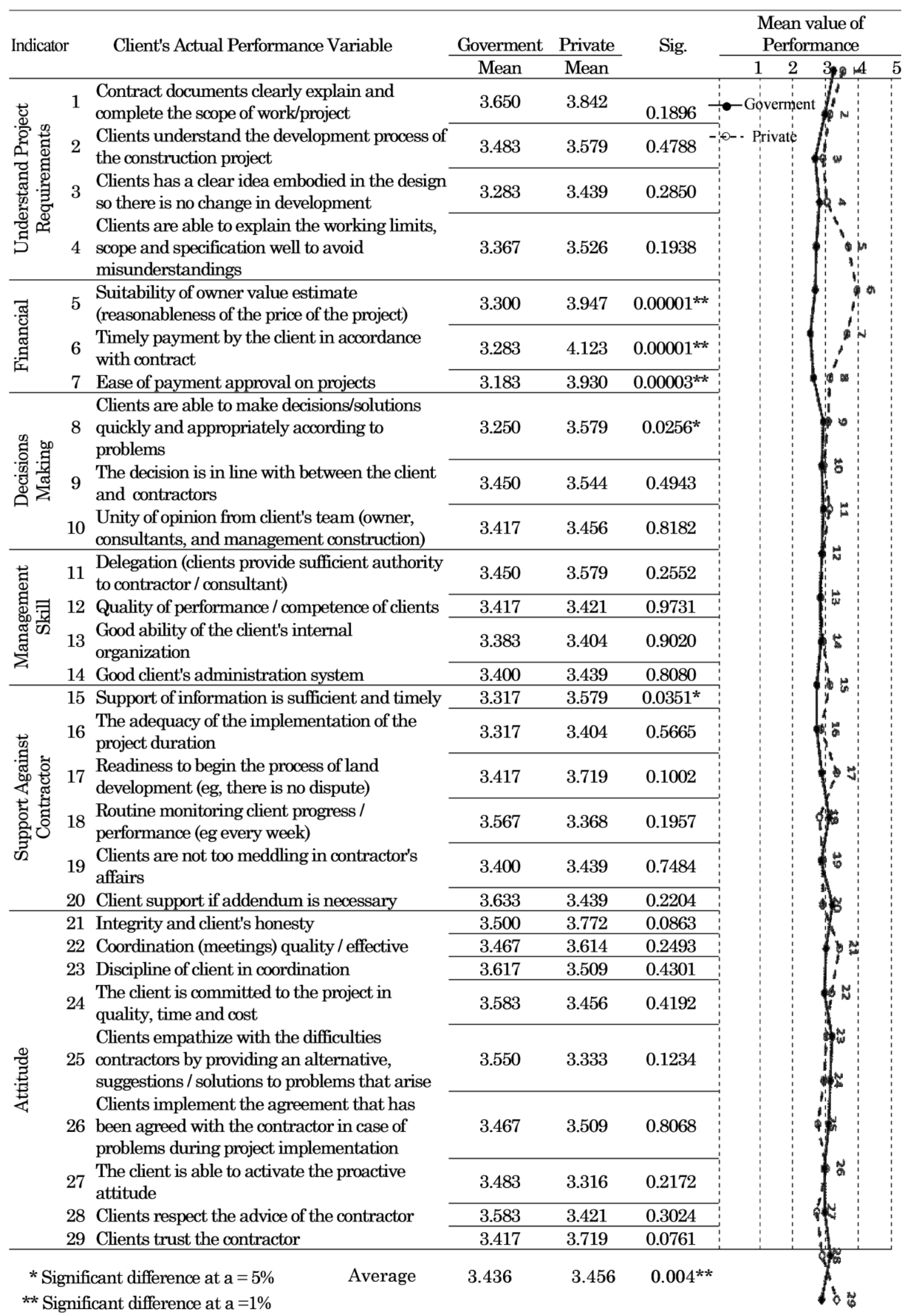


Table 3. Mean Value of Expected Performance for Goverment \& Private Clients

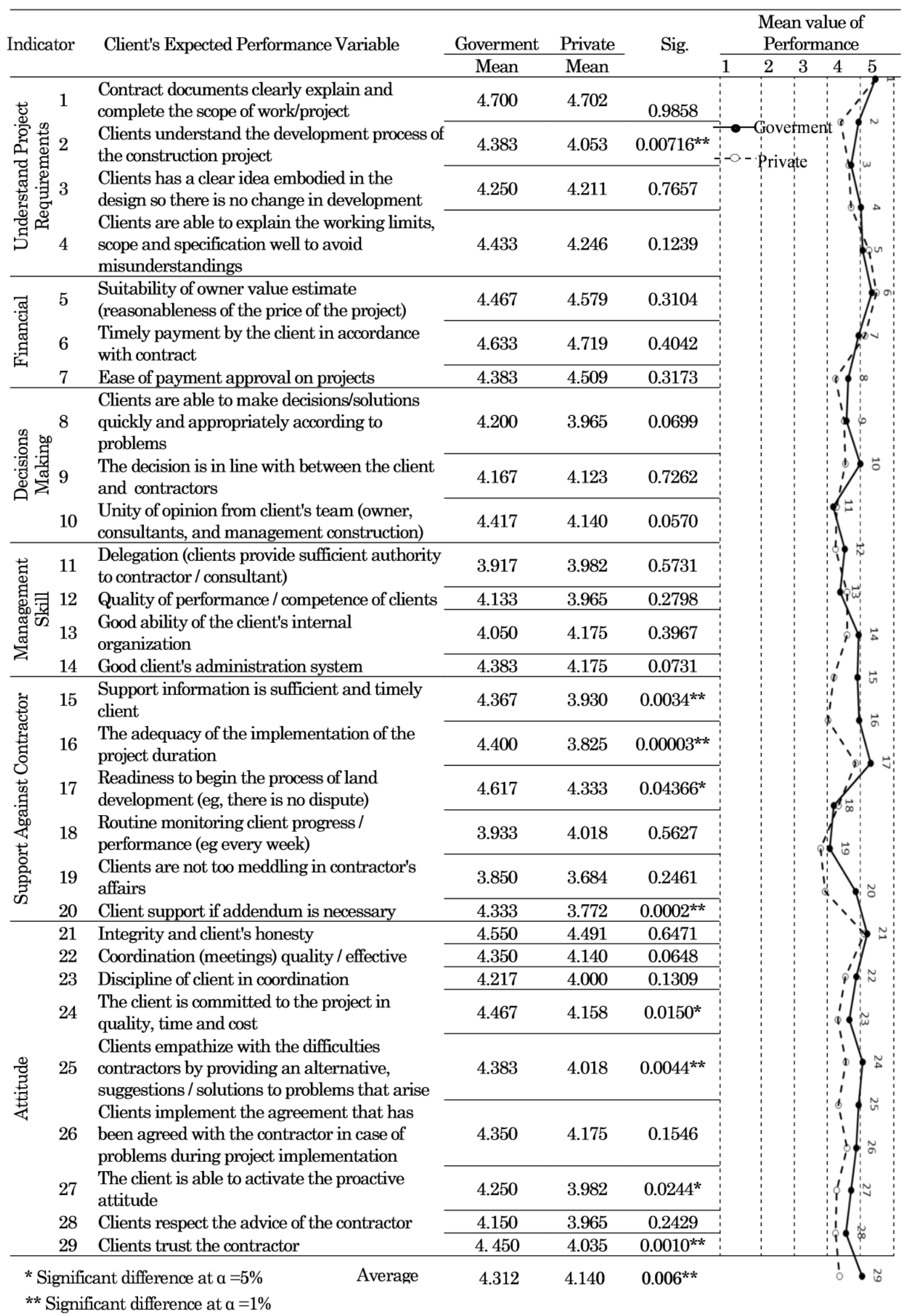


Table 4. Rank of Client's Actual Performanc

\begin{tabular}{|c|c|c|c|c|}
\hline \multirow{2}{*}{ Client's Actual Performance Indicator } & \multicolumn{2}{|c|}{ Goverment } & \multicolumn{2}{|c|}{ Private } \\
\hline & T.Weight & Rank & T.Weight & Rank \\
\hline 6 Timely payment by the client in accordance with contract & 197 & 27 & 235 & 1 \\
\hline $\begin{array}{l}\text { Suitability of owner value estimate (reasonableness of the price of the } \\
\text { project) }\end{array}$ & 198 & 26 & 225 & 2 \\
\hline 7 Ease of payment approval on projects & 191 & 29 & 224 & 3 \\
\hline 1 Contract documents clearly explain and complete the scope of work/project & 219 & 1 & 219 & 4 \\
\hline 21 Integrity and client's honesty & 210 & 8 & 215 & 5 \\
\hline 29 Clients trust the contractor & 205 & 19 & 212 & 6 \\
\hline 17 Readiness to begin the process of land development (e.g. there is no dispute) & 205 & 18 & 212 & 7 \\
\hline 22 Coordination (meetings) quality/effective & 208 & 11 & 206 & 8 \\
\hline 2 Clients understand the development process of the construction project & 209 & 9 & 204 & 9 \\
\hline $\begin{array}{l}8 \text { Clients are able to make decisions/solutions quickly and appropriately } \\
\text { according to problems }\end{array}$ & 195 & 28 & 204 & 10 \\
\hline 11 Delegation (clients provide sufficient authority to contractor / consultant) & 207 & 14 & 204 & 11 \\
\hline 15 Support information is sufficient and timely client & 199 & 24 & 204 & 12 \\
\hline 9 The decision is in line with between the client and contractors & 207 & 13 & 202 & 13 \\
\hline $\begin{array}{l}\text { Clients are able to explain the working limits, scope and specification well } \\
\text { to avoid misunderstandings }\end{array}$ & 202 & 23 & 201 & 14 \\
\hline 23 Discipline of client in coordination & 217 & 3 & 200 & 15 \\
\hline $\begin{array}{l}\text { Clients implement the agreement that has been agreed with the contractor } \\
\text { in case of problems during project implementation }\end{array}$ & 208 & 12 & 200 & 16 \\
\hline 24 The client is committed to the project in quality, time and cost & 215 & 4 & 197 & 17 \\
\hline $\begin{array}{l}\text { Unity of opinion from client's team (owner, consultants, and management } \\
\text { construction) }\end{array}$ & 205 & 16 & 197 & 18 \\
\hline 19 Clients are not too meddling in contractor's affairs & 204 & 21 & 196 & 19 \\
\hline 20 Client support if addendum is necessary & 218 & 2 & 196 & 20 \\
\hline $\begin{array}{l}\text { Clients has a clear idea embodied in the design so there is no change in } \\
\text { development }\end{array}$ & 206 & 15 & 196 & 21 \\
\hline 14 Good client's administration system & 204 & 20 & 196 & 22 \\
\hline 28 Clients respect the advice of the contractor & 215 & 5 & 195 & 23 \\
\hline 12 Quality of performance / competence of clients & 205 & 17 & 195 & 24 \\
\hline 16 The adequacy of the implementation of the project duration & 199 & 25 & 194 & 25 \\
\hline 13 Good ability of the client's internal organization & 203 & 22 & 194 & 26 \\
\hline 18 Routine monitoring client progress / performance (e.g. every week) & 214 & 6 & 192 & 27 \\
\hline $\begin{array}{l}25 \text { Clients empathize with the difficulties contractors by providing an } \\
\text { alternative, suggestions / solutions to problems that arise }\end{array}$ & 213 & 7 & 190 & 28 \\
\hline 27 The client is able to activate the proactive attitude & 209 & 10 & 189 & 29 \\
\hline
\end{tabular}

The top three of actual performance variables of government clients include the clarity of contract documents and complete scope of work, support for addendum, discipline of client in coordination. On the other hand the bottom three of the government client performances are: timely payment, ability to make decisions/solutions quickly and appropriately according to problems, and ease of payment approval. Interestingly, the three variables related to financial indicator which are in the top three of private client performance, are nearly in the bottom three of the government client performance (rank 26, $27,29)$. It may suggest that the private clients are far better than the government ones in terms of financial indicators, i.e. the reasonable value of the project, timely payment and ease of payment approval. In other words, the financial indicator has been found as the weakest performance of the government clients. It is indeed in typical government projects, complex bureaucracy, slow administration process, unreliable staffs and other motives may cause difficulties for payment approval, hence delaying the project payment. In relation with the owner value estimate or the reasonableness of the price of the project, it may suggest that there could be problems with the capabilities of government clients in estimating the project values.

In relation to indicator level, the spider web diagram (Figure 1) and Table 5 show the comparison of the mean values of performance indicators of government and private clients. It can be seen that out of six performance indicators, only the mean values of financial indicator are significantly different (at $\alpha=$ $1 \%$ ), while the other indicators are not significantly different. 
This research provides measures and comparisons of government and private client performance in Indonesian construction industry, which previously may not be available. The research findings are useful to identify areas for improvement of both types of client performance. Improving client performance will contribute positive impacts on the project performance to finish on time, on budget with excellent quality. For contractors, this research may raise awareness of areas of which both types of client performance are typically considered inferior, so that they can come up with anticipation in advance with precise strategies to maintain and improve project performance.

Particularly for government clients, Latham report recommends that "Government should commit itself to being a best practice client...". Government has a strategic role in the construction industry, as it can act as client, regulator, as well as funding provider. It has also the powerful purchasing power as procurer equals to almost a third of construction output. With this strategic position, it can influence the construction sector in many aspects [2].

Although Latham report is in the context of The UK, this recommendation is also relevant for Indonesia context. Strengthening client performance should be one of strategic agendas in Indonesia construction industry, for both types of client. The government should take a strategic action to enhance capacities of clients for the success of the project. This can be done by establishing a construction clients' forum as a media to share knowledge and best practice, benchmarking with peers, etc. In the UK, such clients' forum called The Client Commitments was established focusing on six areas where clients can make positive contributions, i.e. client leadership, procurement and integration, health and safety, design quality, sustainability, commitment to people. In Indonesia context, this forum will help defining and empowering of what so-called good clients.

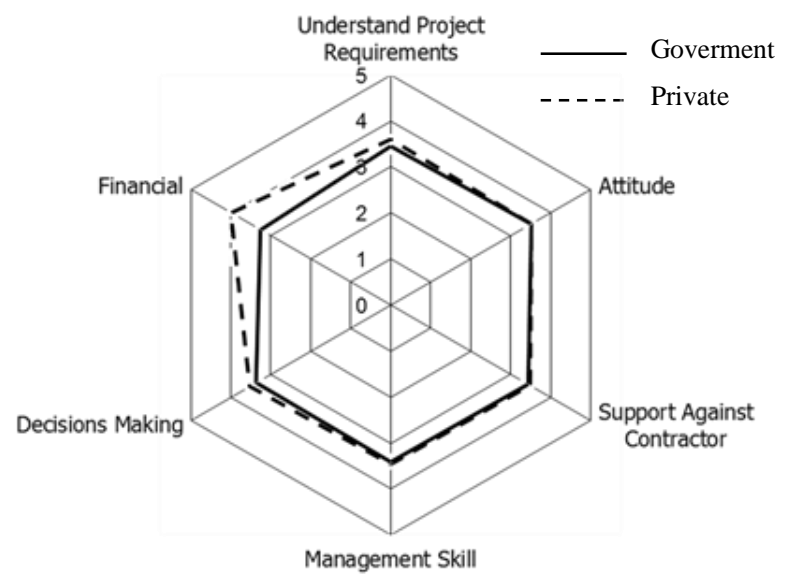

Figure 1. Comparison of Clients' Actual Performance
Table 5. Mean Value Indicator of Actual Performance

\begin{tabular}{lccc}
\hline \multirow{2}{*}{ Indicator } & \multicolumn{2}{c}{ Mean Performance } & \multirow{2}{*}{ Sig. } \\
\cline { 2 - 3 } & Goverment & Private & \\
\hline Understand Project Req. & 3.45 & 3.60 & 0.247 \\
Financial & 3.26 & 4.00 & 0.000 \\
Decisions Making & 3.37 & 3.53 & 0.099 \\
Management Skill & 3.41 & 3.46 & 0.300 \\
Support Against Contractor & 3.44 & 3.49 & 0.530 \\
Attitude & 3.52 & 3.52 & 0.973 \\
\hline
\end{tabular}

\section{Conclusions and Recommendations}

This research compares performance of government and private clients utilizing 29 variables in six performance indicators, i.e. understanding of project requirements, financial, decision making, management skills, supports for contractor and client's attitude. The results show that there is a significant difference (at $\alpha=5 \%$ ) between the actual performance of both types of clients, as well as for their expected performance, which indicates that in general the private clients perform better than the government clients.

Out of the six performance indicators, only the mean values of financial indicator of government and private clients are significantly different (at $\alpha=1 \%$ ), while the others are not significantly different. All the three variables related to financial indicators, i.e. timely payment, suitability of owner value estimate, and ease of payment approval, are in the bottom three of the government client performance (rank 26, 27, 29). However, these three variables are in the top three of private client performance (rank 1,2,3). These results suggest that in terms of financial indicators, the private clients perform way much better in comparison with government clients. The government clients' performance is perceived to be inferior in these financial indicators.

This research provides measures and comparisons of government and private client performance in Indonesian construction industry, which are likely not available beforehand. The research findings are very vital in terms of identifying key variables for improvement of both types of client performance. As a project's success is also largely dependent on the client's knowledge and skills, improving client performance will obviously support the acceleration of the delivery of the project, and in turn will improve the project performance. Following this research, further topic can be done by developing national strategic framework for enhancing construction client capacity.

\section{References}

1. Latham, M., Constructing the Team: Final Report of the Government/Industry Review of Procurement and Contractual Arrangements in The UK Construction Industry, London: HM Stationery Office, 1994. 
2. Business and Enterprise Committee, Construction Matters: Government Response to the Committee's Ninth Report of Session 2007-08, House of Commons, The Stationary Office Limited HC1187, London 14, 2008.

3. Kometa, S.T., Olomolaiye, P.O., and Harris, F.C., Attributes of UK Construction Clients Influencing Project Consultants' Performance, Construction Management and Economics, 12(5), 1994, pp. 433-443.

4. Ryd, N., Facilitating Construction Briefingfrom the Client's Perspective, Nordic Journal of Surveying and Real Estate Research, 1, 2004, pp. 86-100.

5. Hwang, B.G., Zhao, X., and Goh, K.J., Investigating the Client-Related Rework in Building Projects: The Case of Singapore, International Journal of Project Management, 32(4), 2014, pp. 698-708.

6. Rashvand, P. and Majid, M.Z.A., Critical Criteria on Client and Customer Satisfaction for the Issue of Performance Measurement, Journal of Management in Engineering, ASCE, January/February, 2014.

7. Naoum, S.G. and Mustapha, F.H., Influences of the Client, Designer and Procurement Methods on Project Performance, Rowlinson, S. (ed.). Proceedings of CIB-W92 Procurement Systems Symposium, Hong Kong, 1994, pp. 221-228.
8. Department for Business, Enterprise and Regulatory Reform's (BERR), Construction Statistics Annual 2007, Office for National Statistics in United Kingdom, August 2007, (www. statistics.gov.uk).

9. Yunianto, D., Hatmoko, J.U.D., and Hidayat, A., Evaluasi Penerapan Constructability pada Proyek Konstruksi Bangunan Gedung, Media Komunikasi Teknik Sipil, 20(2), Desember 2014.

10. Alinaitwe, H.M., An Assessment of Clients' Performance in Having an Efficient Building Process in Uganda, Journal of Civil Engineering and Management, 14(2), 2008, pp. 73-78.

11. Elforgani, M.S. and Rahmat, I., The Influence of Clients' Qualities on Green Design Performance of Building Projects in Malaysia Descriptive Study, American Journal of Applied Sciences 9(10), 2012, pp. 1668-1677.

12. Soetanto, R., Proverbs, D.G., and Holt, G.D., A Conceptual Tool for Assessing Client Performance in the Construction Project Coalition, Dimensi Teknik Sipil, 4(2), 2002, pp. 60-68.

13. Hatmoko, J.U.D. and Khasani, R.R., Assessing Contractor Satisfaction towards Client Performance in Construction Projects, Applied Mechanics and Materials, 845, 2016, pp. 338-343. 